\title{
Large-scale Production of Clavine Alkaloids by Claviceps fusiformis
}

\author{
By G. T. BANKS, P. G. MANTLE AND CHRISTINE A. SZCZYRBAK \\ Department of Biochemistry, Imperial College, London $\mathrm{SW}_{7} 2 \mathrm{AZ}$
}

(Received 23 October 1973)

\begin{abstract}
S UM MAR Y
A strain of Claviceps fusiformis produced clavine alkaloid (principally agroclavine) in yields of $4 \mathrm{mg} / \mathrm{ml}$ within 6 days when grown in a sucrose-ammonium sulphate-inorganic salts medium in 4001 stirred fermenters. Alkaloid accumulated rapidly during the growth phase, most of the synthesis coinciding with a mycelial growth form consisting of plectenchymatic hyphae, the cells of which resembled the constituent cells of naturally occurring $C$. fusiformis sclerotia. The broth was rendered low in glucan by the activity of a $\beta$-glucanase and this, together with increased fermenter shaft speed, ensured that oxygen supply was not limiting throughout the fermentation. Alkaloid was extracted efficiently from the glucanfree culture filtrate by a solvent extraction procedure involving sequential transfer of the product into $n$-butanol, aqueous tartaric acid and chloroform, followed by crystallization from acetone. Improved alkaloid yield $(6 \mathrm{mg} / \mathrm{ml})$ was obtained by using a modified medium containing increased concentrations of magnesium sulphate, zinc sulphate and potassium dihydrogen orthophosphate, in a 4001 multi-stage fermentation.
\end{abstract}

\section{INTRODUCTION}

Large-scale production of the ergot alkaloids in submerged culture has been confined solely to the commercially important lysergic acid types produced by Claviceps paspali (Arcamone et al. 196I) and C. purpurea (Arcamone et al. 1970). A characteristic feature of alkaloid-producing strains of both $C$. paspali and $C$. purpurea is their instability, whereby they revert to non-producing forms after only a few subcultures (Kobel, 1969; Mantle, I $969 a$ ). By contrast, the clavine alkaloid-producing strains of $C$. fusiformis are usually more stable in submerged culture. Thus strains of this species have been used mainly in biosynthetic investigations (Birch, McLoughlin \& Smith, I960; Groger, Wendt, Mothes \& Weygand, I96I ; Baxter, Kandel, Okany \& Pyke, 1964). As a source of pharmaceuticals C. fusiformis has received much less attention than ergot fungi producing lysergic acid derivatives, since the clavine alkaloids have been reported to possess much weaker oxytocic and vasopressor properties (Hofmann, I96I). However, it has since been shown that agroclavine prevents implantation in mice when the drug is administered orally during the first 2 to 3 days of pregnancy (Mantle, $1969 b$ ). Lactation is also inhibited when agroclavine is administered to mice during late pregnancy (Mantle, I968).

The need for large quantities of pure agroclavine for pharmacological studies stimulated the development of the relatively inexpensive large-scale fermentation process described in this paper. 


\section{METHODS}

Origin of strains. A strain of Claviceps fusiformis (designated 139/2/1), producing high titres of clavine alkaloids $(>3.0 \mathrm{mg} / \mathrm{ml}$ ) in surface culture on a sucrose-asparagine-mineral salts medium (medium $\mathbf{A}$ ), was isolated from a sclerotium parasitic on bulrush millet (Pennisetum typhoides Staph \& Hubbard) grown in Senegal. Agroclavine was the principal $(>90 \%$ ) alkaloid produced but traces of other clavines including elymoclavine, chanoclavine, setoclavine and penniclavine were also present.

Strain $I 39 / 2 / \mathrm{I}$ produced moderate titres of alkaloid $(\mathrm{I} \cdot 2$ to $\mathrm{I} \cdot 4 \mathrm{mg} / \mathrm{ml}$ ) in submerged culture but the fermentations were impeded by restricted aeration as a result of high culture viscosities after the accumulation of an extracellular glucan during the growth phase.

During a programme of strain selection a variant strain ( $139 / 2 / \mathrm{IG})$ arose yielding more alkaloid, partly as a result of the low culture viscosity which was restored after autolysis of the extracellular glucan. Consequently this new strain was used for the development of a large-scale fermentation process.

Maintenance of cultures. Stock cultures were preserved in Pyrex ampoules under liquid nitrogen at $-196^{\circ} \mathrm{C}$. Cultures for liquid nitrogen preservation were grown for 5 to 6 days in submerged culture (medium A). Sterile glycerol (10\%, v/v) was added, and the mixture dispensed ( $\mathrm{I} \mathrm{ml}$ ) into sterile ampoules. The ampoules were cooled slowly from room temperature to $-45^{\circ} \mathrm{C}$ by placing them at $-60^{\circ} \mathrm{C}$ overnight in an insulated, expanded polystyrene box. The ampoules were then quickly immersed in liquid nitrogen.

Cultures for use in experiments were obtained by removing an ampoule from liquid nitrogen, allowing it to attain laboratory temperature, and inoculating medium $\mathrm{A}$ agar slopes which were subsequently grown at $24{ }^{\circ} \mathrm{C}$ and subcultured every two weeks.

Media. Medium A, modified from Stoll, Brack, Hofmann \& Kobel's (I957) medium, was used for surface cultures and seed-stage submerged cultures, and had the following composition (g/l distilled water): sucrose, 100 ; L-asparagine, $10 ; \mathrm{Ca}\left(\mathrm{NO}_{3}\right)_{2} \cdot{ }_{4} \mathrm{H}_{2} \mathrm{O}, \mathrm{I} ; \mathrm{KH}_{2} \mathrm{PO}_{4}$, $0.25 ; \mathrm{MgSO}_{4} \cdot 7 \mathrm{H}_{2} \mathrm{O}, 0.25 ; \mathrm{KCl}, 0.125 ; \mathrm{FeSO}_{4} \cdot 7 \mathrm{H}_{2} \mathrm{O}, 0.033 ; \mathrm{ZnSO}_{4} \cdot 7 \mathrm{H}_{2} \mathrm{O}, 0.027 ; \mathrm{L}$-cysteine hydrochloride, $0.0 \mathrm{I}$; yeast extract, $0 . \mathrm{I} ; \mathrm{pH}$ adjusted to 5.2 with concentrated $\mathrm{NaOH}$. Solid medium contained, in addition, $2 \%(\mathrm{w} / \mathrm{v})$ Oxoid agar and was sterilized by autoclaving at $106^{\circ} \mathrm{C}$ for $15 \mathrm{~min}$.

Medium B was used for production-stage submerged cultures and had the following composition (g/l distilled water): sucrose, 200; $\left(\mathrm{NH}_{4}\right)_{2} \mathrm{SO}_{4}$, II $\cdot 8 ; \mathrm{KH}_{2} \mathrm{PO}_{4}, 0.25 ; \mathrm{MgSO}_{4}$. ${ }_{7} \mathrm{H}_{2} \mathrm{O}, 0.25 ; \mathrm{FeSO}_{4} \cdot 7 \mathrm{H}_{2} \mathrm{O}, 0.033 ; \mathrm{ZnSO}_{4} .7 \mathrm{H}_{2} \mathrm{O}, 0.027 ; \mathrm{pH}$ adjusted to 5.2 with concentrated $\mathrm{NaOH}$. When used in shaken flasks, $2 \%(\mathrm{w} / \mathrm{v}) \mathrm{CaCO}_{3}$ was added to the medium before sterilization, to avoid depression of $\mathrm{pH}$ during subsequent growth of the fungus.

The use and composition of medium $\mathrm{C}$ was the same as medium $\mathrm{B}$, except for increased concentrations of the following inorganic salts $(\mathrm{g} / \mathrm{l}): \mathrm{KH}_{2} \mathrm{PO}_{4}, 0.5 ; \mathrm{MgSO}_{4} \cdot 7 \mathrm{H}_{2} \mathrm{O}, 0.5$; $\mathrm{ZnSO}_{4} \cdot 7 \mathrm{H}_{2} \mathrm{O}$, 0.108.

The conditions employed for sterilization of the different media were scale-dependent, and are fully described below for each scale of operation.

Shaken-flask fermentations. The rotary shakers employed for all submerged flask cultures operated at $200 \mathrm{rev} . / \mathrm{min}$ with a $9 \mathrm{~cm}$ eccentric throw. Under these conditions, an oxygen transfer rate of $38 \mathrm{ml}$ oxygen (at s.t.p.)/100 ml/h was recorded by means of the sulphite oxidation technique of Cooper, Fernstrom \& Miller (1944).

For the seed stage, $100 \mathrm{ml}$ quantities of medium A were dispensed into $500 \mathrm{ml}$ Erlenmeyer flasks. The flasks were closed with cotton-wool plugs and sterilized by autoclaving at $106{ }^{\circ} \mathrm{C}$ for $15 \mathrm{~min}$. The flasks containing medium A were inoculated with a spore suspension 
derived from a I4-day agar slant culture of the organism, grown at $27^{\circ} \mathrm{C}$, to give a final spore concentration in the medium of $4 \times 10^{5} \mathrm{spores} / \mathrm{ml}$. These seed-stage cultures were then incubated for 5 days at $27^{\circ} \mathrm{C}$ on a rotary shaker.

The appropriate production-stage medium was dispensed and sterilized as described above. The flasks were inoculated with $10 \mathrm{ml}$ fully-developed seed-stage culture and incubated at $27^{\circ} \mathrm{C}$ on a rotary shaker for various periods of time (usually Io to I4 days).

Pilot-scale fermentations. The procedure described below is that for carrying out production-stage fermentations on a 4001 scale.

I. Development of laboratory inoculum. The procedure employed in the primary seedstage was identical to that described above for the seed-stage of shaken-flask fermentations. For the secondary seed-stage, I 1 portions of medium A were dispensed into 41 conical flasks fitted with a side-arm. The flasks were closed with cotton-wool plugs and sterilized at I2I ${ }^{\circ} \mathrm{C}$ for I $\mathrm{h}$. They were then inoculated with $\mathrm{I} 00 \mathrm{ml}$ of fully developed primary seedstage culture and incubated for 4 days at $27^{\circ} \mathrm{C}$ on a rotary shaker, as previously described.

2. Five-litre seed-stage fermentation. The vessels employed were glass/stainless steel New Brunswick 51 laboratory fermenters (model FS-600, V. A. Howe, London). Temperature control was achieved by partial immersion of the fermenters in a thermostatically-controlled water bath. Culture aeration was provided by sparging air through a single-orifice sparger into the culture fluid, which was agitated by means of two open-turbine impellers.

Into each fermenter was dispensed 3.11 medium $A$, containing $0.01 \%(\mathrm{v} / \mathrm{v})$ polypropylene glycol antifoam (Polyglycol P-2000, manufactured by Dow Chemical Co.); the vessel outlets were appropriately closed and the fermenters and medium sterilized by autoclaving at I2I ${ }^{\circ} \mathrm{C}$ for I h.

The fermenters were inoculated with $300 \mathrm{ml}$ fully developed secondary seed-stage culture. Subsequent incubation proceeded at $27^{\circ} \mathrm{C}$ for 4 days, culture aeration being facilitated by employing an agitator shaft speed of $400 \mathrm{rev} . / \mathrm{min}$, an air flow rate of $21 / \mathrm{min}$ and an air pressure of 7 to $14 \mathrm{kN} / \mathrm{m}^{2}$. Sterile polypropylene glycol was added as necessary during the fermentation to control foaming.

3. Sixty-litre seed-stage fermentation. The vessels employed were stainless steel 601 fermenters of conventional design. Temperature control was achieved by the automatically regulated flow of cooling water (approx. $15{ }^{\circ} \mathrm{C}$ ) through the fermenter jacket. Culture aeration was provided by sparging air through a ring sparger into the culture fluid, which was agitated by means of a single disc turbine impeller.

Fifty-four litres medium A, containing $0.01 \%(\mathrm{v} / \mathrm{v})$ polypropylene glycol antifoam, were prepared in situ. Medium and fermenter were sterilized at I2 I ${ }^{\circ} \mathrm{C}$ for 20 min by live-steam injection. During medium preparation allowance was made for condensate subsequently formed during sterilization.

The fermenters were inoculated with approx. 61 of fully developed 51 fermenter seedstage culture (i.e. the contents of two such fermenters). Incubation proceeded at $27^{\circ} \mathrm{C}$ for 4 days. An agitator shaft speed of $\mathrm{I} 83 \mathrm{rev} . / \mathrm{min}$ was employed during the first $48 \mathrm{~h}$, being subsequently raised to $367 \mathrm{rev} . / \mathrm{min}$, together with an air flow rate of $601 / \mathrm{min}$ and an air pressure of $100 \mathrm{kN} / \mathrm{m}^{2}$. Polypropylene glycol antifoam was added as necessary to control foaming.

4. Four hundred-litre production-stage fermentation. The vessels employed were stainless steel 4001 fermenters of conventional design. Provisions for temperature control and culture aeration were as previously described for 601 fermenters, except that two disc turbine impellers were employed.

Three hundred litres of appropriately concentrated production-stage medium (medium 
B or C), minus ammonium sulphate but containing $0.01 \%(\mathrm{v} / \mathrm{v})$ polypropylene glycol antifoam, were prepared in situ. Medium and fermenter were sterilized at $12 \mathrm{I}{ }^{\circ} \mathrm{C}$ for $20 \mathrm{~min}$ by live-steam injection. The ammonium sulphate was separately sterilized in a $60 \mathrm{l}$ fermenter

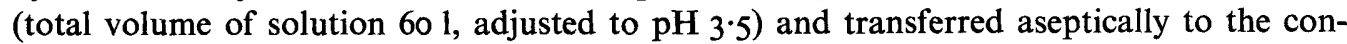
centrated bulk medium in the 4001 fermenter before inoculation. The pre-inoculation volume was thus 3601 , allowance having been made for condensate formed during sterilization.

The fermenters were inoculated with 401 fully developed 601 fermenter seed-stage culture. Subsequent incubation proceeded at $27^{\circ} \mathrm{C}$ for about io days. An agitator shaft speed of I $53 \mathrm{rev} . / \mathrm{min}$ was employed initially; this was raised to $306 \mathrm{rev} . / \mathrm{min}$ when the dissolved oxygen decreased to about $30 \%$ of the saturation value, in order to avoid conditions of oxygen limitation. An air flow rate of $400 \mathrm{l} / \mathrm{min}$ was employed throughout, together with an air pressure of $100 \mathrm{kN} / \mathrm{m}^{2}$. Automatic $\mathrm{pH}$ control was employed to maintain a constant $\mathrm{pH}$ of $5.0 \pm 0 \cdot \mathrm{I}$ throughout the fermentation, by the addition of sterile $30 \%(\mathrm{w} / \mathrm{v}) \mathrm{NaOH}$ solution; a steam-sterilizible glass electrode (model GHQN 28; Electronic Instruments Ltd), together with a remote calomel reference electrode, were employed for $\mathrm{pH}$ measurement whilst control was achieved with a conventional on/off system. Polypropylene glycol antifoam was added as necessary to control foaming.

5. Four hundred-litre half-replacement multistage fermentation. A 4001 fermenter, containing medium $\mathbf{C}$, was inoculated as described above and the fermentation allowed to proceed under normal conditions for 5 days. At this stage, $200 \mathrm{l}$ of culture were run off, and 2001 of double-strength medium $\mathrm{C}$ added; the fermentation was again allowed to proceed under normal conditions. This procedure was repeated at 3 day intervals.

All the fermenters employed were of conventional design. Their characteristic features and relative internal dimensions are given in Table $I$ and Fig. I.

Pilot-scale extraction and purification of agroclavine. A solvent extraction procedure was devised for the isolation of agroclavine from culture fluids. Use was made of the facts that agroclavine is readily soluble in many organic solvents but relatively insoluble in water at alkaline $\mathrm{pH}$ values, whereas when protonated in acid conditions it is freely soluble in aqueous systems. Sequential partition between solvent and aqueous phases at suitably adjusted $\mathrm{pH}$ values, together with a progressive reduction in the volume of successive extracts, effected both a concentration and a purification of the agroclavine. $n$-Butanol was chosen for the initial solvent extraction step in view of its low cost. Since $n$-butanol and water are partially miscible (solubility of water in butanol at $10{ }^{\circ} \mathrm{C}, 19.7 \% \mathrm{v} / \mathrm{v}$; solubility of butanol in water at $10{ }^{\circ} \mathrm{C}, 8.9 \% \mathrm{v} / \mathrm{v}$ ), hexane was used during the procedure both to remove water from butanol extracts and to remove butanol from aqueous phases. Throughout the procedure, the product was maintained under chilled conditions $\left(<5^{\circ} \mathrm{C}\right)$ unless otherwise specified. All liquid/liquid extractions were carried out as batch operations in stainless steel stirred, baffled and jacketed vessels.

The following procedure was employed for the isolation of agroclavine from approximately 4001 of glucan-free culture fiuid. Mycelium was removed from the broth by filtration under pressure through a plate and frame filter press. The culture filtrate was adjusted to $\mathrm{pH} 8.5$ with ammonium hydroxide solution, the product extracted into $0.3 \mathrm{vol}$. $n$-butanol and the butanol extract separated by centrifugation with an Alfa-Laval disc bowl continuous centrifuge. An equal volume of hexane was added to the butanol extract, and the aqueous phase which formed was separated by decantation and discarded. The product-rich butanolhexane mixture was then extracted twice with 0.14 vol. $5 \%(\mathrm{w} / \mathrm{v})$ tartaric acid solution and the two tartaric acid extracts bulked after separation by decantation and/or centrifugation. Butanol was removed from the combined tartaric acid extracts by the addition of an equal 
Table I. Dimensions of pilot plant fermenters

Fermenter dimension or characteristic

\begin{tabular}{lcc}
\multicolumn{3}{c}{ Fermenter scale (l) } \\
\hline 5 & 60 & 400 \\
3.4 & 60 & 400 \\
4 & 4 & 4 \\
2 & 1 & 2 \\
4 & 4 & 8 \\
Open & Disc & Disc \\
Single & Ring & Ring \\
orifice & & \\
I.52 & I.20 & I.43 \\
0.55 & 0.38 & 0.40 \\
I.I5 & $2 \cdot 14$ & I.14 \\
I.00 & - & I.57 \\
0.64 & I.07 & 0.85 \\
0.1 I & 0.10 & 0.08
\end{tabular}

For explanation of symbols see Fig. I.

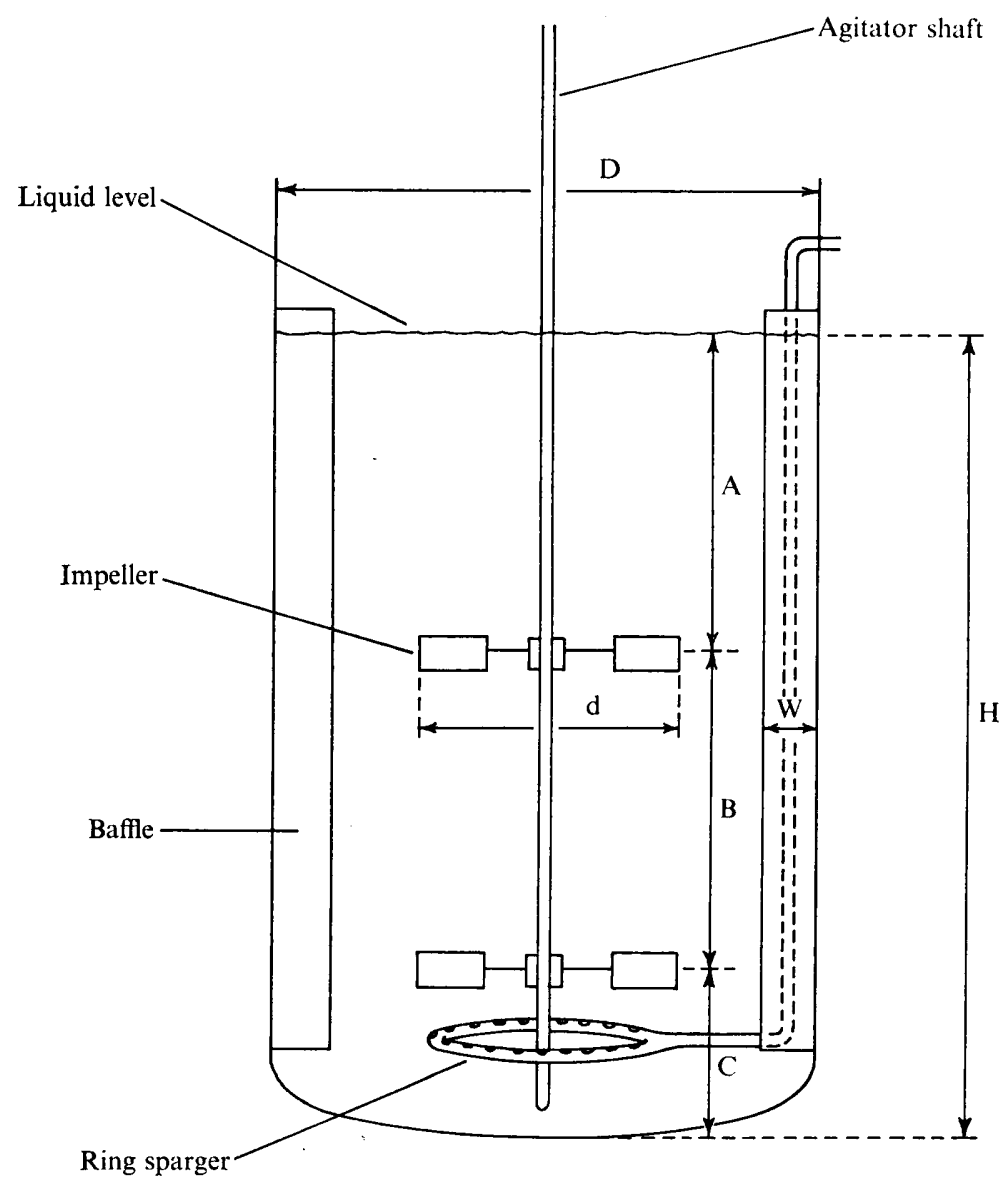

Fig. I. Diagrammatic representation of internal design of fermenter. 
Table 2. Procedure for large-scale extraction of agroclavine

Culture filtrate $\mathrm{pH} 8 \cdot 5$

$$
\begin{aligned}
& \downarrow \leftarrow \frac{1}{3} \text { Vol. } n-\mathrm{BuOH} \\
\text { BuOH extract } & \\
\downarrow & \leftarrow \text { Equal vol. } n \text {-hexane }
\end{aligned}
$$

$\mathrm{H}_{2} \mathrm{O} / \mathrm{BuOH} /$ hexane mixture

$$
\begin{gathered}
\downarrow \rightarrow \text { Discarded aqueous phase } \\
\text { BuOH/hexane mixture } \\
\downarrow \leftarrow 2 \times \frac{1}{7} \text { Vol. } 5 \% \text { aqueous tartaric acid }
\end{gathered}
$$

Combined tartaric acid extracts

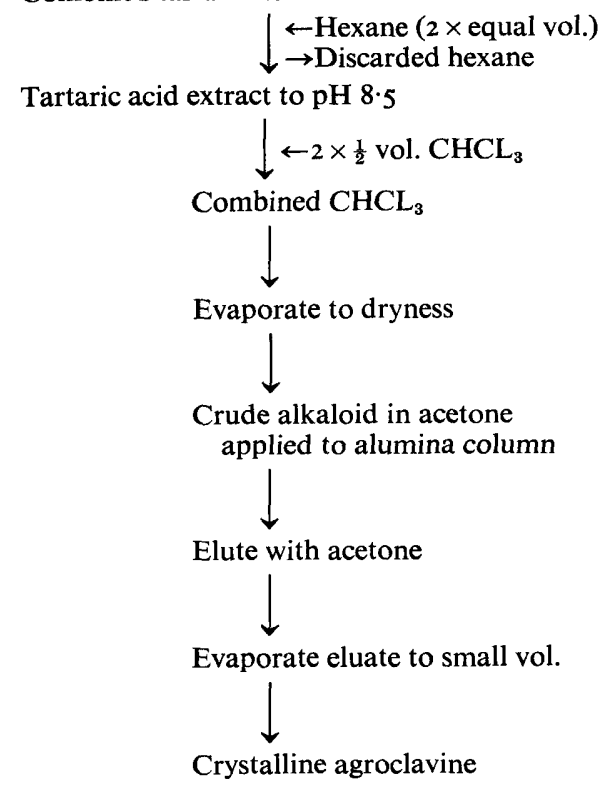

volume of hexane and the subsequent removal of the hexane-butanol phase by decantation on two separate occasions. The $\mathrm{pH}$ of the combined tartaric acid extract was then adjusted to 8.5 with ammonium hydroxide solution and the agroclavine extracted from it by means of two half-volume extractions with chloroform; the chloroform extracts were separated from the aqueous phase by centrifugation and subsequently bulked. The combined chloroform extract was evaporated to dryness under reduced pressure to yield a crude, coloured (brown) agroclavine preparation initially by means of a climbing-film evaporator (Quickfit Jobling Laboratory Division, Stone, Staffordshire) and subsequently in an Apex Evaporator type 263A (Apex Construction Ltd, London).

Crystalline agroclavine was obtained from the crude preparation on a laboratory scale by dissolution in acetone, removal of coloured impurities on an alumina column, concentration of the acetone column eluate under reduced pressure in a rotary film evaporator and, finally, crystallization was induced by chilling the concentrate.

The extraction and purification procedures referred to above are illustrated in diagrammatic form in Table 2. 
The overall efficiency of obtaining a crude alkaloid extract (after chloroform extract concentration) from culture filtrate was approximately $70 \%$. The principal loss occurred during concentration of the chloroform extract. Crystalline agroclavine was obtained from the crude alkaloid with an efficiency of $80 \%$.

Analytical procedures. Unless otherwise stated, the maximum absorbancies of coloured complexes were measured on a Unicam SP 600 spectrophotometer (Unicam Instruments, Cambridge) using a I cm light path.

I. Alkaloid. Suitably diluted culture filtrate $(5 \mathrm{ml})$ was mixed with $10 \mathrm{ml}$ of Van Urk Reagent (p-dimethylaminobenzaldehyde, $0.125 \mathrm{~g} ; 65 \% \mathrm{v} / \mathrm{v}_{2} \mathrm{HOO}_{4}, \quad 100 \mathrm{ml} ; 5 \% \mathrm{w} / \mathrm{v}$ $\mathrm{FeCl}_{3} \cdot 6 \mathrm{H}_{2} \mathrm{O}, 0 . \mathrm{I} \mathrm{ml}$ ). The absorbance of the blue colour formed was measured after $10 \mathrm{~min}$ with an Eel Colorimeter (Evans Electroselenium Ltd, Halstead, Essex) at $570 \mathrm{~nm}$, and compared with standard solutions of pure agroclavine (dissolved in $\mathrm{I} \%$ tartaric acid) in the range 0 to $25 \mu \mathrm{g} / \mathrm{ml}$, within which a linear relationship between absorbance and alkaloid concentration existed.

2. Mycelial dry weight. A sample (50 to $75 \mathrm{ml}$ ) of culture was filtered through dried weighed filter paper (Whatman no. 54I), washed twice with distilled water, and dried to constant weight at $70^{\circ} \mathrm{C}$. Highly viscous cultures (containing glucan) were diluted at least 5 to 10 times before processing.

3. Glucan. The filtrate and washings from the mycelial dry weight determinations were stirred with an equal volume of ethanol. The precipitated glucan was collected on a glass rod, transferred to dried weighed filter paper and dried to constant weight at $70^{\circ} \mathrm{C}$.

4. Glucose. Free glucose in the culture filtrate was measured after diluting the culture filtrate to contain Io to $100 \mu \mathrm{g}$ glucose $/ \mathrm{ml}$. A $\mathrm{x} \cdot 0 \mathrm{ml}$ sample was mixed with glucose-oxidase reagent $(3.0 \mathrm{ml})$ and the absorbance of the blue colour formed was measured after $10 \mathrm{~min}$ at $625 \mathrm{~nm}$. The glucose-oxidase reagent had the following constitution: 'Fermcozyme' [Hughes \& Hughes (Enzymes) Ltd, Romford, Essex], $0.5 \mathrm{ml} ; 0.5 \mathrm{M}$-acetate buffer $\mathrm{pH} 5.2$, $93.5 \mathrm{ml}$; peroxidase solution ( $20 \mathrm{mg}$ in $100 \mathrm{ml}$ acetate buffer), $5.0 \mathrm{ml} ; \mathrm{I} \%(\mathrm{v} / \mathrm{v}) O$-tolidine (in absolute ethanol), $\mathrm{I} \cdot 0 \mathrm{ml}$. The reagent was stored in the dark at 3 to $4{ }^{\circ} \mathrm{C}$.

5. Sucrose. This was determined by an auto-analyser method (Dickerson, Mantle \& Szczyrbak, 1970), or manually as follows. Culture filtrate (Io ml) was incubated at $37^{\circ} \mathrm{C}$ for $\mathrm{I} h$ with two drops of yeast invertase concentrate (BDH). After suitable dilution the glucose liberated by the enzymic hydrolysis was determined with glucose-oxidase reagent. A calibration graph was prepared for glucose by plotting absorbance units against glucose concentration in the range 10 to $100 \mu \mathrm{g} / \mathrm{ml}$. The sucrose content was calculated as the difference between hydrolysed and unhydrolysed culture filtrate.

6. Reducing sugar. Reducing sugar in culture filtrate from which glucan had been precipitated was determined as follows. A $5.0 \mathrm{ml}$ sample of the ethanolic culture filtrate was hydrolysed with $4 \mathrm{~N}-\mathrm{H}_{2} \mathrm{SO}_{4}(5.0 \mathrm{ml})$ for $30 \mathrm{~min}$ in a boiling water bath. After rapid cooling and neutralization with $2 \mathrm{~N}-\mathrm{NaOH}$ ( $10 \mathrm{ml}$ ), the volume was made up to $20 \mathrm{ml}$ with distilled water. Fehling's solution A $\left(\mathrm{CuSO}_{4} \cdot 5 \mathrm{H}_{2} \mathrm{O}, 6.93 \% \mathrm{w} / \mathrm{v} ; 5.0 \mathrm{ml}\right)$, Fehling's solution B (potassium sodium tartrate, $3.4 \% \mathrm{w} / \mathrm{v} ; \mathrm{NaOH}, 14.2 \% \mathrm{w} / \mathrm{v} ; 5.0 \mathrm{ml}$ ), and hydrolysed sample $(20 \mathrm{ml})$ were placed in a $100 \mathrm{ml}$ conical flask (together with 3 or 4 glass beads) and boiled

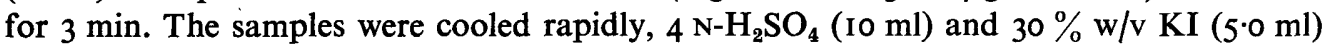
were added, and the liberated iodine titrated with $0.05 \mathrm{~N}-\mathrm{Na}_{2} \mathrm{~S}_{2} \mathrm{O}_{3}$ using starch as the indicator. A blank was prepared using distilled water $(20 \mathrm{ml})$ instead of the sample. A standard graph was constructed relating volume of sodium thiosulphate solution to reducing sugar concentration in the range 5-30 $\mathrm{mg}$ glucose $/ \mathrm{ml}$.

7. Cell-associated sucrase. In order to assess the result of sucrase activity, culture samples 
were taken at intervals during fermentation and assayed chromatographically for sugars as follows. Culture filtrate $(2.5 \mu \mathrm{l})$ was applied to Whatman no. I paper and developed by descending chromatography in $n$-propanol-ethylacetate-water $(7: 1: 2)$ for $22 \mathrm{~h}$ at room temperature. After drying, the chromatograms were sprayed to saturation with a solution of the following composition: 0 -phthalic acid, $\mathrm{I} \cdot 7 \mathrm{~g}$; aniline (redistilled over $\mathrm{Zn}$ ), $\mathrm{I} \cdot 0 \mathrm{ml}$; $40 \%(\mathrm{w} / \mathrm{v})$ trichloroacetic acid, $5.0 \mathrm{ml}$; glacial acetic acid, $5.0 \mathrm{ml}$; made up to $100 \mathrm{ml}$ with absolute ethanol. The sugars appeared as brown spots after heating the dried papers at $120^{\circ} \mathrm{C}$ for $5 \mathrm{~min}$.

8. Inorganic phosphate. Suitably diluted culture filtrate ( $1 \cdot 0 \mathrm{ml})$, distilled water $(25 \mathrm{ml})$, sodium molybdate solution $\left(2.5 \% \mathrm{w} / \mathrm{v}\right.$ in $\left.10 \mathrm{~N}-\mathrm{H}_{2} \mathrm{SO}_{4} ; 5 \mathrm{ml}\right)$ and $0.15 \%(\mathrm{w} / \mathrm{v})$ hydrazine $(2.0 \mathrm{ml})$ were made up to $50 \mathrm{ml}$ with distilled water and heated at $100{ }^{\circ} \mathrm{C}$ for $10 \mathrm{~min}$. After cooling rapidly the volumes were readjusted to $50 \mathrm{ml}$ and the absorbance of the blue colour determined at $830 \mathrm{~nm}$. A calibration curve in the range 0 to $50 \mu \mathrm{g}$ phosphorus $/ \mathrm{ml}$ was constructed by using standard $\mathrm{KH}_{2} \mathrm{PO}_{4}$ solutions.

9. Ammonium nitrogen. Suitably diluted culture filtrate $(0.6 \mathrm{ml})$ was mixed with $20 \%$ $(\mathrm{w} / \mathrm{v}) \mathrm{NaOH}(3.4 \mathrm{ml})$. After I min, $0.8 \mathrm{ml}$ alkaline phenol reagent $(25 \mathrm{~g}$ phenol made up to I $00 \mathrm{ml}$ with $20 \% \mathrm{w} / \mathrm{v} \mathrm{NaOH}$ ) was added and the solution allowed to stand for a further $2 \mathrm{~min}$. Sodium hypochlorite solution ( $12 \%, \mathrm{w} / \mathrm{v}$, available chlorine; $0.42 \mathrm{ml}$ ) was then added and the absorbance of the blue colour determined at $630 \mathrm{~nm}$ within 8 to io min. A calibration curve was prepared of $\mu \mathrm{g}$ nitrogen/ml against absorbancy units using $\left(\mathrm{NH}_{4}\right)_{2} \mathrm{SO}_{4}$ solution in the concentration range $\mathrm{I} 2$ to $45 \mu \mathrm{g} \mathrm{N} / \mathrm{ml}$.

I0. Culture-filtrate lipid. Glucan was first removed from the culture filtrate by the addition of an equal volume of ethanol. After evaporation to the original volume the treated filtrate was extracted with petroleum spirit (b.p. 40 to $60{ }^{\circ} \mathrm{C}$; twice, with equal volumes). The combined solvent extract was evaporated and the residual oil weighed.

I I. Mycelial lipid. Washed mycelium was dried in vacuo over $\mathrm{P}_{2} \mathrm{O}_{5}$ and $\mathrm{CaCl}_{2}$ and a finely milled sample $(0.5 \mathrm{~g})$ was extracted with chloroform-methanol $(2: \mathrm{I} ; 200 \mathrm{ml})$ at room temperature for $9 \mathrm{~h}$, followed by further extraction at $37^{\circ} \mathrm{C}$ overnight. The solvent was filtered through fat-free cellulose thimbles (Whatman) and shaken with o. I N-KCl (40 ml) to effect a separation of the chloroform. The chloroform was removed, and the aqueous phase washed with an equal volume of chloroform. The combined chloroform extract was evaporated and the residual oil taken to constant weight.

12. Dissolved-oxygen concentration. This measurement was made by using a Teflon coil containing oxygen-free argon as the reference gas (after Roberts \& Shepherd, 1968). Recording was achieved by a Kent Recorder (Kent Cambridge Ltd, Cambridge) coupled to a Hersch meter.

13. Oxygen consumption. Input air and exhaust gas from fermenters was dried by passage through a chilled-water condenser followed by silica gel. The oxygen content of the dried gases was determined with a Servomex Paramagnetic Oxygen Analyser (model DCL 83; Servomex Controls Ltd, Crowborough, Sussex) connected to a Kent Recorder. The oxygen consumption of the culture was calculated from the difference between input and output measurements.

I4. $\mathrm{CO}_{2}$ evolution. Exhaust gas was dried by passage through a chilled-water condenser followed by anhydrous $\mathrm{CaSO}_{4}$, and the $\mathrm{CO}_{2}$ content determined by a Hilger and Watts Infra-red Gas Analyser (model SC/F; Hilger \& Watts Ltd, London N.W.I), coupled to a Foster Micro-amp Recorder (Foster Cambridge Ltd, London Nio 2NA). A correction for the $\mathrm{CO}_{2}$ present in input air was applied.

I5. Rheological measurements. In order to characterize the rheological properties of 
samples of culture fluid, shear stress measurements were carried out over a range of shear rates by means of a Contraves Rheomat model 15 Couette viscometer; such measurements were performed at a minimum of ten different shear rates for each sample. The true shear rates were obtained by adjusting for non-Newtonian flow behaviour in the viscometer with the correction factors reported by Calderbank \& Moo-Young (1959). All the culture fluids were found to obey the power law, $\tau=K \gamma^{n}$, where $\tau$ is the shear stress (dynes $\left./ \mathrm{cm}^{2}\right)$ and $\gamma$ the shear rate $\left(\mathrm{s}^{-1}\right)$; the values of the consistency coefficient $(K$, in $\mathrm{g} / \mathrm{cm} / \mathrm{s})$ and flowbehaviour index $(n)$ were calculated from this relationship. The values of the average apparent viscosity in the fermenter were derived in accordance with the procedures described by Metzner \& Otto (1957); a value of I I.5 was assumed for the proportionality factor relating agitator shaft speed and average shear rate in the fermenter, this figure being the average of those reported by Metzner \& Otto (1957) and Calderbank \& Moo-Young (I959). Reynold's number was calculated from the normal equation for stirred baffled vessels, $N_{\mathrm{Re}}=\rho N D^{2} / \mu a$, where $\mu a$ is the average apparent viscosity in the fermenter (poise), $N_{\mathrm{Re}}$ is Reynold's number, $\rho$ is the liquid density $\left(\mathrm{gm} / \mathrm{cm}^{3}\right), N$ the agitator shaft speed (rev./s), and $D$ the impeller diameter (cm).

\section{RESULTS}

\section{Development of an optimum production medium}

Preliminary studies (Szczyrbak, 1972) in shake flasks on the selection of suitable carbon sources showed that in a simple defined medium either sucrose or glucose $(2 \% \mathrm{w} / \mathrm{v})$ supported maximum mycelial growth $(8.5 \mathrm{mg} / \mathrm{ml})$ and allowed alkaloid production, whereas mannitol and mannose were less well utilized. Fructose, maltose, lactose, galactose, glycerol, sorbitol and starch supported little growth. Thus sucrose was selected on economic grounds and was used initially at a concentration of $10 \% \mathrm{w} / \mathrm{v}$ (medium A).

Neither nitrate nor tryptophan supported growth as sole nitrogen sources. Tests on a wide range of other sources of nitrogen (Table 3) showed that good growth and alkaloid production could occur if a suitable $\mathrm{pH}$ value was maintained during the fermentation. However, the best nitrogen source for alkaloid production was $\left(\mathrm{NH}_{4}\right)_{2} \mathrm{SO}_{4}$ provided that the $\mathrm{pH}$ value could be maintained above $5 \cdot 0$. This was adequately achieved in shake flasks by the addition of $\mathrm{CaCO}_{3}$.

The optimum concentrations of sucrose and $\left(\mathrm{NH}_{4}\right)_{2} \mathrm{SO}_{4}$ for maximum alkaloid production were determined in a modification of medium $\mathrm{A}$, from which $\mathrm{Ca}\left(\mathrm{NO}_{3}\right)_{2}, \mathrm{KCl}$, cysteine hydrochloride and yeast extract were omitted. The assessment of twenty-five sucrose/ ammonium sulphate combinations (Table 4) showed that $200 \mathrm{~g} / \mathrm{l}$ sucrose and I $\cdot 8 \mathrm{~g} / \mathrm{l}$ $\left(\mathrm{NH}_{4}\right)_{2} \mathrm{SO}_{4}(=2.5 \mathrm{mg} \mathrm{N} / \mathrm{ml})$ gave a maximum alkaloid yield of $3.7 \mathrm{mg} / \mathrm{ml}$ within 9 days, at which stage no glucan remained in the culture filtrate. Thus this medium (medium B) was tested in a 4001 fermentation in which $\mathrm{pH}$ was controlled by automatic additions of $\mathrm{NaOH}$.

\section{$400 \mathrm{l}$ batch fermentation process}

The course of a typical 4001 fermentation is illustrated in Fig. 2. High yields $(4 \mathrm{mg} / \mathrm{ml})$ of alkaloid were obtained, which slightly exceeded the yield in shake flasks (Table 4). Rapid alkaloid accumulation occurred during the mycelial growth phase, but ceased when the growth rate declined at 5 to 6 days.

Alkaloid production ceased although approximately $30 \%$ of the batched nitrogen source remained unused. A relatively high concentration of reducing sugar remained at the end of the fermentation. Sugar chromatography showed that sucrose had disappeared within the 


\section{Table 3. Effect of various nitrogen sources on growth and alkaloid production in medium $A$}

The nitrogen sources replaced asparagine in medium $\mathbf{A}$ on an equivalent $\mathbf{N}$ basis. Cultures were grown for 9 days in production stage shake flasks. Morphology was sclerotial except for those cultures grown in valine and serine which showed the sphacelial growth form.

\begin{tabular}{|c|c|c|c|c|c|}
\hline Nitrogen source & $\begin{array}{l}\text { Mycelial } \\
\text { dry weight } \\
\text { (mg/ml) }\end{array}$ & $\begin{array}{c}\text { Alkaloid } \\
\text { titre* } \\
(\mathrm{mg} / \mathrm{ml})\end{array}$ & Final pH & $\begin{array}{l}\text { Estimated } \\
\text { residual } \\
\text { glucan } \\
(- \text { to }+++)\end{array}$ & $\begin{array}{l}\text { Approximate } \\
\text { cost of } \\
\text { N-source in } \\
197 \mathrm{I}(f / \mathrm{kg})\end{array}$ \\
\hline L-Asparagine & 13.60 & $I \cdot 49 \pm 0.04$ & $5 \cdot 45$ & - & II $\cdot 0$ \\
\hline L-Aspartic acid & 13.53 & $1.62 \pm 0.04$ & 6.00 & - & $9 \cdot 0$ \\
\hline L-Sodium glutamate & 14.83 & $1 \cdot 68 \pm 0.17$ & $5 \cdot 75$ & - & $I \cdot 5$ \\
\hline L-Proline & 13.48 & $1.64 \pm 0.04$ & $5 \cdot 15$ & - & 94.0 \\
\hline L-Phenylalanine & $17 \cdot 10$ & $1 \cdot 17 \pm 0.04$ & $6 \cdot 40$ & - & $36 \cdot 0$ \\
\hline L-Alanine & IO. I 8 & $1 \cdot 21 \pm 0.00$ & $5 \cdot 40$ & - & $35 \cdot 0$ \\
\hline L-Valine & $17 \cdot 60$ & $x \cdot 36 \pm 0.06$ & $5 \cdot 60$ & - & $30 \cdot 0$ \\
\hline L-Serine & $14 \cdot 60$ & $0.31 \pm 0.01$ & $5 \cdot 30$ & + & I 13.0 \\
\hline Glycine & $12 \cdot 00$ & $1.35 \pm 0.01$ & $5 \cdot 10$ & - & $2 \cdot 0$ \\
\hline Urea & $I \cdot 75$ & $0.03 \pm 0.00$ & $9 \cdot 08$ & + & $I \cdot O$ \\
\hline Ammonium citrate & 14.60 & $1.40 \pm 0.07$ & $4 \cdot 60$ & - & I. of \\
\hline Ammonium tartrate & 13.45 & $0.57 \pm 0.01$ & $3.40 t$ & $++t$ & $1 \cdot 6 t$ \\
\hline Ammonium succinate & 10.55 & $1.62 \pm 0.02$ & 5.50 & - & $2 \cdot 0+$ \\
\hline Ammonium DL-malate & $15 \cdot 36$ & $I .87 \pm 0.04$ & 5.52 & - & $2 \cdot 4^{t}$ \\
\hline$\left(\mathrm{NH}_{4}\right)_{2} \mathrm{SO}_{4}$ & 4.85 & $0.04 \pm 0.00$ & $2 \cdot 70+$ & + & 0.8 \\
\hline \multirow{2}{*}{$\begin{array}{l}\left(\mathrm{NH}_{4}\right)_{2} \mathrm{SO}_{4}+2 \%(\mathrm{w} / \mathrm{v}) \\
\mathrm{CaCO}_{3}\end{array}$} & $19 \cdot 26$ & $I .94 \pm 0.01$ & $6 \cdot 50$ & - & 0.8 \\
\hline & $\begin{array}{l}\text { ean of } 3 \mathrm{fla} \\
\text { ow pH value } \\
\text { ost of free a }\end{array}$ & $\pm \mathrm{st}$ & $a m n$ & ptake. & \\
\hline
\end{tabular}

first 5 days, leaving fructose and fructofuranoside polymers. Glucose, which remained after fructosyl transferase action on sucrose, was preferentially utilized by the fungus and was barely detectable after 4 days. Thus some other nutrients, such as inorganic phosphate, magnesium or zinc, may have been limiting for alkaloid production and fungal growth.

Inorganic phosphate was taken up rapidly within 2 or 3 days of inoculation and its rapid uptake coincided with high respiratory activities.

Although mycelial morphology throughout the fermentation was principally in the sclerotial form consisting of short branched hyphae, frequently septate with the cells full of lipid, some sporulation occurred during the lag and early exponential phase (about 2 to 3 days from inoculation) indicating a transient phase of sphacelial growth with its characteristically lower lipid content. This could account for the fall in the mycelial lipid at $I$ to 3 days after inoculation. There was also a decrease in the mycelial lipid content towards the end of the fermentation. However, the free lipid contents $(0.2$ to $0.4 \%, \mathrm{w} / \mathrm{v})$ of the culture filtrate samples at Io days were not sufficient for this decrease to be accounted for by the release of lipid from the mycelium by autolysis of the cells. Thus the dry weight of mycelium which accumulated after day 6 may have been due to the proliferation of some sphacelial cells together with the sclerotial cells.

Respiration measurements during fermentation showed that the $\mathrm{O}_{2}$ consumption and $\mathrm{CO}_{2}$ evolution rose rapidly to maximum values at the beginning of the exponential phase, but then decreased gradually as the growth rate declined. The high respiratory rates were transitory since the true exponential growth phase appeared to be relatively short ( 24 to $48 \mathrm{~h}$ ).

In view of the viscous nature of Claviceps fusiformis cultures, rheological studies were 
Table 4. Effect of varying concentrations of sucrose and $\left(\mathrm{NH}_{4}\right)_{2} \mathrm{SO}_{4}$ in medium $\mathrm{B}$ on alkaloid production by $C$. fusiformis after 9 days growth in production-stage shake flasks

\begin{tabular}{|c|c|c|}
\hline $\begin{array}{l}\text { Sucrose } \\
(\mathrm{g} / \mathrm{l})\end{array}$ & $\begin{array}{l}\left(\mathrm{NH}_{4}\right)_{2} \mathrm{SO}_{4} \\
(\mathrm{mg} \mathrm{N} / \mathrm{ml})\end{array}$ & $\begin{array}{l}\text { Alkaloid titre* } \\
\text { (mg/ml) }\end{array}$ \\
\hline 50 & $\begin{array}{r}3 \\
5 \\
7 \\
10\end{array}$ & $\begin{array}{l}1.24 \pm 0.03 \\
0.81 \pm 0.01 \\
0.39 \pm 0.08 \\
0.06 \pm 0.00\end{array}$ \\
\hline 100 & $\begin{array}{l}2 \cdot 0 \\
2 \cdot 5 \\
3 \cdot 0 \\
4 \cdot 0 \\
5 \\
7 \\
10\end{array}$ & $\begin{array}{l}2.71 \pm 0.03 \\
2.79 \pm 0.03 \\
2 \cdot 19 \pm 0.08 \\
1.93 \pm 0.02 \\
1 \cdot 11 \pm 0.06 \\
0.29 \pm 0.00 \\
0.07 \pm 0.00\end{array}$ \\
\hline I 50 & $\begin{array}{c}2 \cdot 0 \\
2 \cdot 5 \\
3 \cdot 0 \\
4 \cdot 0 \\
5 \\
7 \\
10\end{array}$ & $\begin{array}{l}3.25 \pm 0.15 \\
3.19 \pm 0.05 \\
3.05 \pm 0.03 \\
1.86 \pm 0.10 \\
0.58 \pm 0.07 \\
0.19 \pm 0.01 \\
0.07 \pm 0.01\end{array}$ \\
\hline 200 & $\begin{array}{l}2 \cdot 0 \\
2 \cdot 5 \\
3 \cdot 0 \\
4 \cdot 0 \\
5 \\
7 \\
10\end{array}$ & $\begin{array}{l}3.31 \pm 0.03 \\
3.67 \pm 0.03 \\
3.18 \pm 0.00 \\
2.10 \pm 0.21 \\
0.50 \pm 0.05 \\
0.19 \pm 0.01 \\
0.06 \pm 0.00\end{array}$ \\
\hline
\end{tabular}

carried out on whole broth samples from a typical 4001 scale batch fermentation (Table 5). The glucan content reached a maximum value on the fourth day of the fermentation. As expected at this stage, the culture fluid exhibited highly pseudoplastic non-Newtonian properties, as indicated by the low value of the flow behaviour index. The consistency coefficient of the fluid and the average apparent viscosity within the fermenter (as defined by Metzner \& Otto, 1957) also reached maximum values at this time. Subsequent hydrolysis of the glucan by a constitutive $\beta$-I,3 glucanase restored the culture viscosity to its original low value. These results clearly indicate that the viscous nature of the culture fluid in the early stages of the fermentation was principally due to the glucan, since in the later stages, when the glucan content was low and the mycelial dry weight high, the average apparent viscosity values were extremely low. The small extent to which the mycelium affected the viscosity of the culture fluid is unusual and is thought to be associated with the sclerotial (i.e. non-filamentous) nature of the mycelium. The dilatant properties $(n>1)$ exhibited by the culture fluid in the absence of glucan, or in the presence of low concentrations of glucan, were unexpected.

The Reynold's number was also calculated at different stages throughout the fermentation and this reached a minimum value after 4 days because of the high culture viscosity. However, the Reynold's number was maintained at values above $10^{4}$ throughout, indicating that the highly desirable conditions of turbulent flow existed at all stages of the fermentation.

The dissolved-oxygen concentration reached a minimum value at the fourth day, because of the limitation imposed upon the oxygen supply by the high culture viscosity. Dissolved 


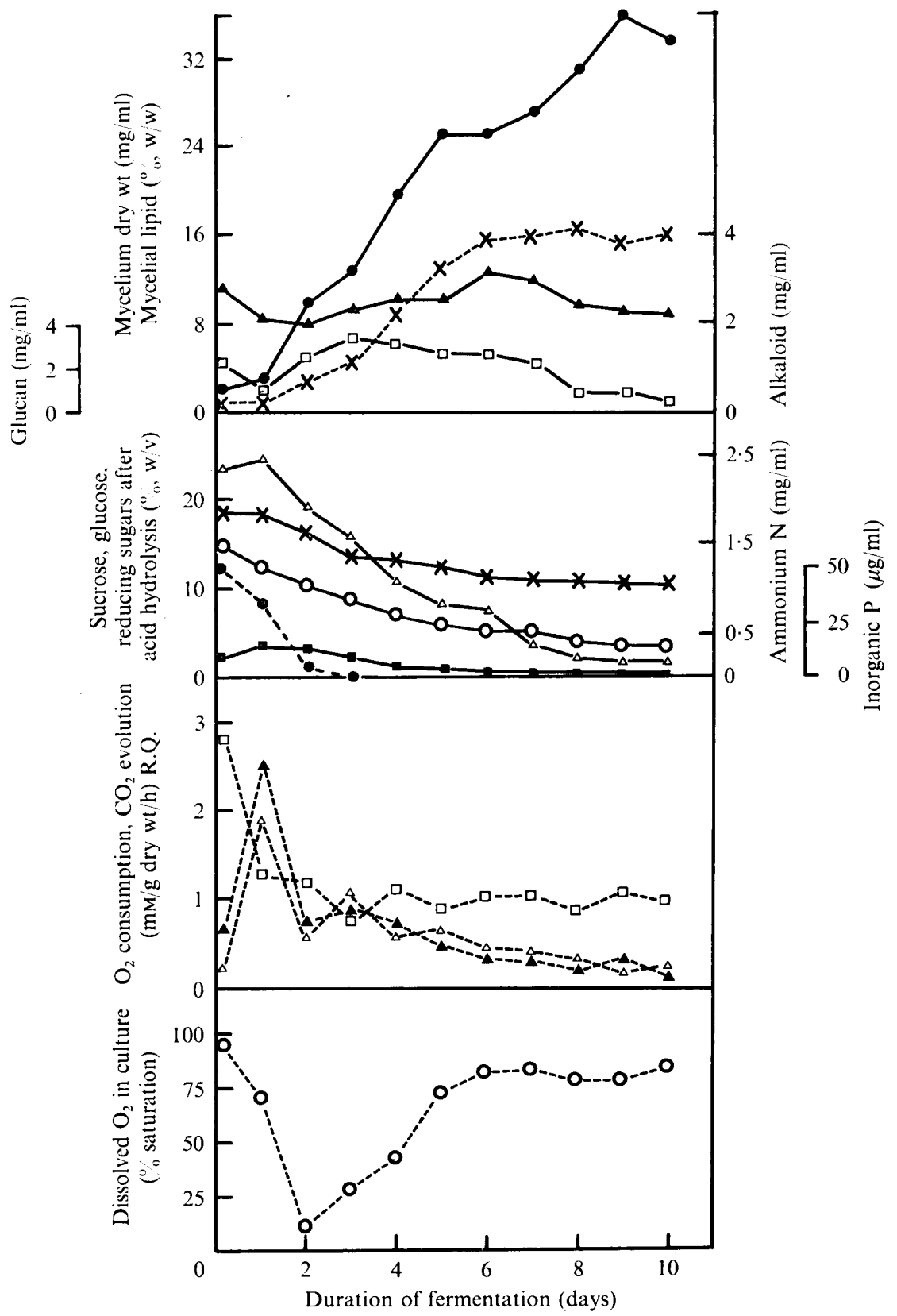

Fig. 2. Course of Claviceps fusiformis (strain $139 / 2 / 1 \mathrm{G}$ ) fermentation in a 4001 fermenter. Mycelium; $\square-\mathbf{\square}$, glucose; $\times---\times$, alkaloid; $\mathbf{\Delta - \Lambda}$, mycelial lipid; $\bigcirc-O$, sucrose; $\square-\square$, glucan; $\triangle \perp \triangle$, ammonium $N$; ---0 , inorganic $P$; $\times-\times$, reducing sugar; $\square$, glucan; $\triangle-\mathrm{Q} . \Delta-\mathrm{qCO}_{2} ; \triangle---\triangle, \mathrm{qO}_{2} ; \mathrm{O}_{----} \mathrm{O}$, dissolved oxygen. 
Table 5. Rheological data for 400 l fermentation in medium $B$

\begin{tabular}{|c|c|c|c|c|c|c|c|}
\hline Days & $\begin{array}{l}\text { Shaft } \\
\text { speed }\end{array}$ & $n$ & $\underset{(\mathrm{g} / \mathrm{cm} / \mathrm{s})}{K}$ & $\begin{array}{c}\mu a \\
\text { (centipoise) }\end{array}$ & $N_{\mathrm{Re}}{ }^{*}$ & $\begin{array}{c}\text { Dissolved } \\
\text { oxygen concn } \\
\text { (\% saturation) }\end{array}$ & $\begin{array}{l}\text { Glucan } \\
\text { (mg/ml) }\end{array}$ \\
\hline 0 & I 53 & - & - & - & - & - & $I \cdot 26$ \\
\hline I & 153 & I 59 & $9.3 \times 10^{-4}$ & 0.69 & $3.15 \times 10^{5}$ & 78 & $2 \cdot 27$ \\
\hline 2 & I 53 & $1 \cdot 39$ & $4.2 \times 10^{-3}$ & I'59 & $1 \cdot 37 \times 10^{5}$ & 64 & I.97 \\
\hline 3 & 306 & 0.38 & $6 \cdot 8$ & $53 \cdot 25$ & $8.17 \times 10^{3}$ & 35 & $4 \cdot 23$ \\
\hline 4 & 306 & 0.43 & $3 \cdot 9$ & $37 \cdot 52$ & $1 \cdot 16 \times 10^{4}$ & 42 & 3.53 \\
\hline 5 & 306 & 0.88 & $1 \cdot 6 \times 10^{-1}$ & $10 \cdot 24$ & $4.25 \times 10^{4}$ & 73 & $2 \cdot 34$ \\
\hline 6 & 306 & $I \cdot 36$ & $6.7 \times 10^{-3}$ & 2.97 & $1.46 \times 10^{5}$ & 89 & $2 \cdot 36$ \\
\hline 7 & 306 & $I \cdot 6 I$ & $1 \cdot 4 \times 10^{-3}$ & $1 \cdot 71$ & $2.54 \times 10^{5}$ & $8 I$ & 0.00 \\
\hline 8 & 306 & I $\cdot 57$ & $1 \cdot 3 \times 10^{-3}$ & $I \cdot 33$ & $3.27 \times 10^{5}$ & 78 & 0.00 \\
\hline 9 & 306 & 1.87 & $2.0 \times 10^{-4}$ & 0.70 & $6.21 \times 10^{5}$ & 87 & 0.00 \\
\hline 10 & 306 & $I \cdot 69$ & $6.1 \times 10^{-4}$ & 1.03 & $4.22 \times 10^{5}$ & 90 & 0.00 \\
\hline
\end{tabular}

* Calculated on the assumption that $\rho$ (liquid density) $=\mathbf{I} \mathrm{g} / \mathrm{cm}^{3}$.

\section{Table 6. Effect of inorganic phosphate on alkaloid production}

Duplicate flasks assayed after 9 days growth in production stage shake flasks in medium B containing different inorganic phosphate concentrations.

$\begin{array}{cccccc}\begin{array}{c}\text { Initial } \\ \mathrm{KH}_{2} \mathrm{PO}_{4}\end{array} & \begin{array}{c}\text { Mean alkaloid } \\ \text { titre* }\end{array} & \begin{array}{c}\text { Mean final } \\ \text { sucrose concn } \\ (\mu \mathrm{mg} / \mathrm{ml})\end{array} & \begin{array}{c}\text { Mean final } \\ \text { glucose concn } \\ (\mathrm{mg} / \mathrm{ml})\end{array} & \begin{array}{c}\text { Estimate of } \\ \text { glucan concn } \\ (- \text { to }+++)\end{array} & \begin{array}{c}\text { Mycelial } \\ \text { morphology }\end{array} \\ 0.050 & 0.27 \pm 0.01 & 164.0 & 30.6 & + & \text { Sphacelial, few spores } \\ 0.075 & \mathbf{I} \cdot 35 \pm 0.00 & 129.0 & 22.4 & - & \text { Sphacelial, no spores } \\ 0.100 & 2.22 \pm 0.1 \mathrm{I} & 100.4 & 16.0 & - & \text { Sclerotial, no spores } \\ 0.150 & 3.32 \pm 0.04 & 6 \mathrm{I} .6 & 9.4 & - & \text { Sclerotial, no spores } \\ 0.200 & 4.09 \pm 0.09 & 37.2 & 4.6 & - & \text { Sclerotial, no spores } \\ 0.250 & 4.18 \pm 0.04 & 29.4 & 7.3 & - & \text { Sclerotial, no spores } \\ 0.300 & 4.27 \pm 0.01 & 19.5 & 5.9 & + & \text { Sclerotial, few spores } \\ 0.400 & 4.87 \pm 0.09 & 5.5 & 0.4 & ++ & \text { Sclerotial, few spores } \\ 0.500 & 5.90 \pm 0.10 & 4.1 & 0.4 & +++ & \text { Sclerotial, many spores } \\ 0.750 & 5.20 \pm 0.09 & 3.0 & 0.4 & +++ & \text { Sclerotial, many spores } \\ \mathbf{I} \cdot 000 & 5.20 \pm 0.00 & 3.3 & 0.7 & +++ & \text { Sclerotial, many spores } \\ & & * \text { Standard error indicated. } & & \end{array}$

oxygen subsequently increased, partly owing to glucan hydrolysis and partly to the increase in agitator shaft speed at this time. The fact that the dissolved oxygen concentration never fell below $35 \%$ of the saturation value suggests that the oxygen supply was not limiting at any stage.

\section{Further medium development in shake flasks}

Having obtained alkaloid titres in 4001 fermentation equivalent to those obtained in shake flasks, further investigations were made in shake flasks to determine the optimal concentrations of phosphate, magnesium, iron and zinc.

The phosphate concentration in medium $\mathrm{B}$ was varied in the range 0.05 to $\mathrm{I} \cdot 00 \mathrm{~g} / \mathrm{l}$ (Table 6). At all concentrations phosphate was totally absorbed from the medium within the 9 day fermentation period, but maximum alkaloid yield $(6 \mathrm{mg} / \mathrm{ml})$ occurred at about $0.5 \mathrm{~g}$ $\mathrm{KH}_{2} \mathrm{PO}_{4} /$, coinciding with maximum depletion of sucrose. It was notable that the higher phosphate concentration caused purple mycelial pigmentation, increased sugar uptake, and also increased culture viscosity which was at least in part due to residual glucan. 
Table 7. The effect of different levels of magnesium sulphate in medium B on alkaloid production

Triplicate flasks assayed after 9 days in production stage.

$\begin{array}{cc}\mathrm{MgSO}_{4} .7 \mathrm{H}_{2} \mathrm{O} & \begin{array}{c}\text { Mean alkaloid titre* } \\ (\mathrm{m} / \mathrm{l})\end{array} \\ 0.05 & 4.32 \pm 0.15 \\ 0.10 & 4.86 \pm 0.15 \\ 0.25 & 4.48 \pm 0.08 \\ 0.50 & 5.34 \pm 0.09\end{array}$

* Standard error indicated.

Table 8. Effect on alkaloid production of concentrations of iron and zinc in medium $B$

Triplicate flasks assayed after 9 days in production stage.

$\begin{array}{ccc}\mathrm{ZnSO}_{4} .7 \mathrm{H}_{2} \mathrm{O} & \begin{array}{c}\mathrm{FeO}_{4} .7 \mathrm{H}_{2} \mathrm{O} \\ (\mathrm{g} / \mathrm{l})\end{array} & \begin{array}{c}\text { Alkaloid* } \\ (\mathrm{mg} / \mathrm{ml})\end{array} \\ 0.014 & 0.017 & 3.82 \pm 0.14 \\ & 0.033 & 4.14 \pm 0.05 \\ 0.027 & 0.066 & 4.00 \pm 0.13 \\ & 0.017 & 4.48 \pm 0.18 \\ 0.054 & 0.033 & 4.40 \pm 0.08 \\ & 0.066 & 4.36 \pm 0.05 \\ & 0.017 & 4.73 \pm 0.12 \\ & 0.033 & 5.00 \pm 0.08 \\ & 0.066 & 4.87 \pm 0.12\end{array}$

* Standard error indicated.

Table 9. The combined effect of different zinc, magnesium and inorganic phosphate concentrations on alkaloid production in medium $B$

Triplicate flasks assayed after 9 days growth in production stage.

$\begin{array}{cc}\mathrm{MgSO}_{4} .7 \mathrm{H}_{2} \mathrm{O} & \mathrm{ZnSO}_{4} .7 \mathrm{H}_{2} \mathrm{O} \\ (\mathrm{g} / \mathrm{l}) & (\mathrm{g} / \mathrm{l}) \\ 0.25 & 0.027 \\ 0.50 & 0.054 \\ 0.50 \dagger & 0.108 \\ 0.50 & 0.054 \\ 0.10 & 0.054\end{array}$

$\mathrm{KH}_{2} \mathrm{PO}_{4}$
$(\mathrm{~g} / \mathrm{l})$
0.25
0.50
0.50
0.75
0.50

Mean alkaloid titre* (mg/ml)

$3.57 \pm 0.15$

$5 \cdot 37 \pm 0 \cdot 03$

$5.99 \pm 0.06$

$5 \cdot 34 \pm 0 \cdot 14$

$5 \cdot 69 \pm 0 \cdot 10$
Estimate of glucan concn $(-$ to +++$)$

$$
\begin{gathered}
- \\
++ \\
+++ \\
+++ \\
+++
\end{gathered}
$$

* Standard error indicated.

$\dagger$ Medium C.

Medium B was therefore modified by doubling the phosphate concentration, after which the effect of different concentrations of magnesium, iron and zinc was investigated. Magnesium concentration did not appear to be critical (Table 7) and a change in iron concentration was of no advantage (Table 8). However, an increase in the zinc concentration raised alkaloid titres to $5 \mathrm{mg} / \mathrm{ml}$ (Table 8). Further assessment of the effect of magnesium, zinc and phosphate concentrations (Table 9 ) indicated that medium B could be modified to advantage, giving alkaloid yields of $6 \mathrm{mg} / \mathrm{ml}$ at 9 days, by doubling the concentration of $\mathrm{MgSO}_{4}$ and $\mathrm{KH}_{2} \mathrm{PO}_{4}$ and quadrupling the concentration of $\mathrm{ZnSO}_{4}$. This new medium was designated medium $\mathrm{C}$. 


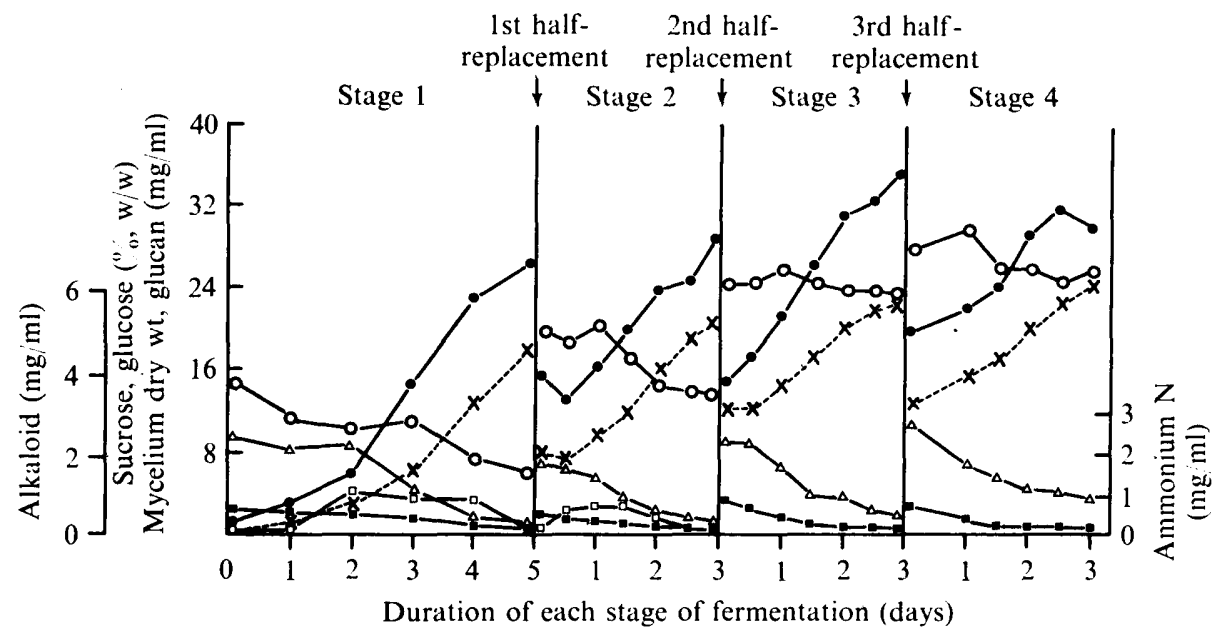

Fig. 3. Course of a 4001 multistage fermentation of $C$. fusiformis (strain $139 / 2 / \mathrm{IG}$ ). Mycelium; $\square-\square$, glucose; $\square-\square$, glucan; $\times---x$, alkaloid; $O-O$, sucrose; $\triangle \longrightarrow \triangle$, ammonium $\mathbf{N}$.

\section{Table Io. Comparison of alkaloid production in medium $C$ in seed and} production-stage laboratory culture

Group I: triplicate flasks of medium $\mathrm{C}$ inoculated with spore suspension and incubated for $\mathbf{1 7}$ days (i.e. single-stage batch culture). Group 2: triplicate flasks of medium $\mathrm{C}$ inoculated with $10 \%(\mathrm{v} / \mathrm{v})$ of 7-day-old Group I flasks and incubated for 17 days (i.e. medium $\mathrm{C}$ used for both seed and production stages).

\begin{tabular}{ccc} 
& \multicolumn{2}{c}{ Alkaloid $(\mathrm{mg} / \mathrm{ml})$} \\
\cline { 2 - 3 } After 12 days* & After I7 days* \\
Group 2 & $4.63 \pm 0.07$ & $6.51 \pm 0.09$ \\
& * Standard error indicated. & $6.55 \pm 0.15$
\end{tabular}

All these tests had been performed in production-stage shake-flask cultures with medium A for the seed stage. Thus the suitability of medium $\mathrm{C}$ as a seed medium and as a single-stage batch medium for shake flasks was assessed (Table I0). Alkaloid titres of $6.5 \mathrm{mg} / \mathrm{ml}$ occurred in both seed and production stage cultures within 17 days. The lower titres of seed cultures at $\mathbf{2}$ days can be attributed to the lag in establishing sclerotial mycelium in flasks inoculated with spores.

\section{0 l Half-replacement multi-stage process}

The superior nature of medium $\mathbf{C}$ for alkaloid production was confirmed in a multi-stage fermentation. The course of this fermentation is illustrated in Fig. 3. By maintaining the concentration of nutrients at a non-limiting value in half-replacement culture, progressively higher alkaloid titres (up to $6 \mathrm{mg} / \mathrm{ml}$ ) were achieved in 4001 multi-stage fermentation. In all stages of this fermentation, alkaloid production proceeded at a high rate in linear fashion and, as in previous 4001 fermentations in medium B, coincided with the rapid growth phase. Glucan was entirely absent from the third and fourth stages of the fermentation, probably because of the accumulation of glucanase in the culture. During the third and fourth stages of the fermentation very little sucrose had been broken down, suggesting that sucrase activity was low. 


\section{DISCUSSION}

This method for the large-scale production of agroclavine by batch or half-replacement fermentation has several important features. Utilizable nitrogen and carbon sources remained in abundance at the end of the fermentation. Through the action of a $\beta$-fructofuranosidase similar to that which operates in the utilization of sucrose by Claviceps purpurea (Bassett et al. 1972; Dickerson, 1972), sucrose was converted to a series of fructofuranoside polymers by fructosyl transfer and the residual glucose was preferentially utilized by the fungus. Some of the higher polymers were partly broken down later in the fermentation. $\beta$-Glucanase hydrolysed the glucan, which commonly accumulates during $C$. fusiformis growth on sucrose or glucose (Tonolo \& Udvardy-Nagy, 1968; Buck, Chen, Dickerson \& Chain, I968; Dickerson et al. I970), and later restored availability of free glucose for uptake by the fungus. This enzyme rendered the third and fourth stages of half-replacement fermentations free from glucan. The rapid uptake of phosphate was similar to that observed for other Claviceps species (Arcamone et al. 1970; Mantle, I973). Zinc ions stimulated agroclavine production, a feature also observed by Rosazza, Kelleher \& Schwarting (1967) in Claviceps paspali fermentations which yielded alkaloid. Optimum $\mathrm{Zn}^{++}$concentration was found to be 25 times greater than that used by Tonolo \& Udvardy-Nagy (I968).

Alkaloid synthesis closely followed growth, as expressed by dry weight accumulation. In high-alkaloid yielding fermentations the growth form of the cells, of which the shortbranched septate hyphae are composed, resembled those comprising the medullary tissue of naturally occurring sclerotia of Claviceps fusiformis (Mantel \& Szczyrbak, 1972). However, a certain amount of alkaloid can also be synthesized by sphacelial hyphae of $C$. fusiformis. Alkaloid synthesis by this species is not as closely restricted to sclerotial cells as has been demonstrated in Claviceps purpurea (Mantle \& Tonolo, 1968; Bassett et al. 1972). The sclerotium-like growth form was also associated with the activity of the $\beta$-glucanase, by which glucan was eliminated thereby maintaining adequate dissolved oxygen concentration. This, in turn, facilitated both the production of high yields of alkaloid and its subsequent extraction from the culture filtrate. The $\beta$-glucanase activity was also reflected in the changing rheological properties of the cultures during fermentation.

The high viscosity and pseudoplastic nature $(n<1)$ of the whole fermentation culture, coinciding with the presence of high concentrations of glucan, was to be expected, since polysaccharide solutions generally exhibit pseudoplastic properties. Subsequent hydrolysis of the glucan restored the original low viscosity of the culture even in the presence of increased quantities of mycelium. Under these conditions the whole culture exhibited dilatant properties $(n>1)$. This unusual feature was undoubtedly associated with the sclerotial form of the hyphal fragments, which contrasted with the more filamentous form in which fungal hyphae usually grow in submerged culture and on which they confer pseudoplastic properties.

Values of the Reynold's number $\left(N_{\mathrm{Re}}\right)$ remained above $10^{4}$ throughout the fermentation, indicating that conditions of turbulent flow existed. Such conditions are desirable if maximum aeration is to be provided under defined agitation conditions. Culture aeration was not limiting, since the values of the dissolved oxygen concentration did not fall below $35 \%$ saturation at any stage.

Thus maintenance of well-aerated non-viscous cultures, by the combined action of the $\beta$-glucanase and the persistence of the sclerotium-like growth form, allowed the production of high alkaloid titres to be supported in an inexpensive nutrient medium. 
We wish to thank Professor Sir Ernst Chain for interest and support during this work and the Science Research Council for a Research Studentship to C.A.S. The assistance of the pilot plant staff in carrying out large scale fermentations is gratefully acknowledged.

\section{REFERENCES}

Arcamone, F., Chain, E. B., Ferretti, A., Minghetti, A., Pennella, P., Tonolo, A. \& Vero, L. (1961). Production of a new lysergic acid derivative in submerged culture by a strain of Claviceps paspali Stevens \& Hall. Proceedings of the Royal Society B 155, 26-54.

Arcamone, F., Cassinelli, G., Ferni, G., Penco, G., Pennella, P. \& Pol, C. (1970). Ergotamine production and metabolism of Claviceps purpurea strain $275 \mathrm{FI}$ in stirred fermenters. Canadian Journal of Microbiology 16, 923-931.

Bassett, R. A., Chain, E. B., Corbett, K., Dickerson, A. G. F. \& Mantle, P. G. (I972). Comparative metabolism of Claviceps purpurea in vivo and in vitro. Biochemical Journal 127, 3-4 P.

Baxter, R. M., Kandel, S. I., Okany, A. \& Pyke, R. G. (1964). Biosynthesis of ergot alkaloids. The origin of the $N$-methyl group. Canadian Journal of Chemistry 42, 2936-2938.

Birch, A. J., McLoughlin, B. J. \& Sмiтh, H. (1960). The biosynthesis of the ergot alkaloids. Tetrahedron Letters $7, \mathrm{I}-3$.

Buck, K. W., Chen, A. W., Dickerson, A. G. \& Chain, E. B. (1968). Formation and structure of extracellular glucans produced by Claviceps species. Journal of General Microbiology $\mathbf{5 1}$, 337-352.

Calderbank, P. H. \& Moo-Young, M. B. (1959). The production of power consumption in the agitation of non-Newtonian fluids. Transactions of the Institute of Chemical Engineers 37, 26-33.

Cooper, C. M., Fernstrom, G. A. \& Miller, S. A. (1944). Gas-liquid contactors. Industrial Engineering Chemistry 36, 504-509.

Dickerson, A. G. (1972). A $\beta$-D-fructofuranosidase from Claviceps purpurea. Biochemical Journal 129, 263-272.

Dickerson, A. G., Mantle, P. G. \& Szczyrbak, C. A. (1970). Autolysis of extracellular glucans produced in vitro by a strain of Claviceps fusiformis. Journal of General Microbiology 6o, 403-415.

Groger, D., Wendt, H. J., Mothes, K. \& Weygand, F. (1959). Untersuchungen zur Biosynthese der Mutterkornalkaloide. Zeitschrift für Naturforschung 14B, 355-358.

Hofmann, A. (196I). Recent developments in ergot alkaloids. Australasian Journal of Pharmacy 42, 7-I 8.

Koвel, H. (1969). Degenerationsprobleme be Produktionsstämmen von Claviceps. Pathologia microbiologia 34, I49-25I.

MANTLE, P. G. (1968). Inhibition of lactation in mice following feeding with ergot sclerotia (Claviceps fusiformis Loveless) from the bulrush millet (Pennisetum typhoides Staph and Hubbard) and an alkaloid component. Proceedings of the Royal Society B I70, 423-434.

MANTLE, P. G. (1969a). Development of alkaloid production in vitro by a strain of Claviceps purpurea from Spartina townsendii. Transactions of the British Mycological Society 52, 38I-392.

MANTLE, P. G. $(1969 b)$. Interruption of early pregnancy in mice by oral administration of agroclavine and sclerotia of Claviceps fusiformis (Loveless). Journal of Reproduction and Fertility 18, 8I-88.

MANTLE, P. G. (I973). Production of ergot alkaloids in vitro by Sphacelia sorghi. Journal of General Microbiology 75, 275-28I.

Mantle, P. G. \& Szczyrbak, C. A. (1972). Factors affecting clavine alkaloid production in submerged cultures of Claviceps fusiformis. Journal of General Microbiology 73, xxii.

MANTLE, P. G. \& TONOLO, A. (1968). Relationship between the morphology of Claviceps purpurea and the production of alkaloids. Transactions of the British Mycological Society 5I, 499-505.

METzNer, A. B. \& OTto, R. E. (1957). Agitation of non-Newtonian fluids. Association of the Institute of Chemical Engineers Journal 3, 3-10.

RoberTs, A. N. \& SHEPHERd, P. G. (1968). Dissolved oxygen measurement in continuous aseptic fermentation. Process Biochemistry 3, 23-24.

Rosazza, J. P., Kelleher, W. J. \& Schwarting, A. E. (I967). Production of lysergic acid derivatives in submerged culture. IV. Inorganic nutrition studies with Claviceps paspali. Applied Microbiology 15, $1270-1283$.

Stoll, A., Brack, A., Hofmann, A. \& Kobel, H. (1957). U.S. Patent 2,809,920.

Szczyrbak, C. A. (1972). Production of Clavine alkaloids in vitro by Claviceps fusiformis. Ph.D. thesis, University of London.

Tonolo, A. \& Udvardy-Nagy, E. (I968). Production of clavine alkaloids by Claviceps fusiformis Loveless in submerged culture. Acta microbiologica Academiae scientiarum hungaricae 15, 29-40. 